\title{
ENTREVISTA
}

\section{A Arte do Segredo: esoterismo, segredo, sigilo e dissimulação política nos séculos XV e XVI}

El investigador Francisco de Paula Souza de Mendonça Jr. ha defendido una Tesis Doctorado en Historia, cuyo título es "A Arte do Segredo: esoterismo, segredo, sigilo e dissimulação política nos séculos XV e XVI" en la Universidad Federal de Minas Gerais, Belo Horizonte, Brasil, el 28 de Noviembre de 2014. Francisco nació en 1979 en Brasil.

El autor nos ha concedido la siguiente entrevista.

¿Cuáles fueron los motivos que le llevó a enfocar su investigación hacia el Esoterismo?

Desde criança sou fascinado pelo universo do sobrenatural, pelos assuntos de cunho esotérico. Tanto os elementos da dita cultura pop quanto os oriundos do chamado "mundo real" voltados a temáticas como essa me prenderam a atenção. Resolvi graduar-me em História para conseguir saber mais sobre dois temas que sempre me cativaram: o Esoterismo e a Idade Média. Quando descobri a possibilidade da pesquisa, da construção de um conhecimento histórico dinâmico, diferente da forma enciclopédica como a disciplina havia sido anteriormente apresentada a mim, tratei de buscar por obras que tratassem do Esoterismo, principalmente no mundo medieval. Logo, no começo do curso um amigo me apresentou a Steganographia do abade Johannes Trithemius (1462-1516) e desde 2003 venho procurando explorar esse aspecto histórico tão rico representado pelo Esoterismo.

¿Cuáles fueron las fuentes que ha utilizado?

O corpus documental central da tese foi construído a partir da discussão das obras Steganographia e Polygraphia do abade Johannes Trithemius, e também das obras Magie Naturalis e De Furtivis Literarum Notis vulgo De Ziferis, ambas de autoria no italiano Giambattista della Porta (1535- c. 1615). Ainda que eu tenha centrado o trabalho em tais fontes, busquei dialogar com outros materiais, como $O$ príncipe de Nicolau Maquiavel, De Occulta Philosophia de Cornelius Agrippa e La piazza universale di tutte le professioni del mondo de Tommaso Garzoni. 
¿Cuáles fueron las principales dificultades con las que se ha encontrado? ¿Cómo las ha superado?

Trabalhar com História do Esoterismo e História Medieval, a partir do Brasil, apresentou duas dificuldades mais gritantes: a disponibilidade de fontes e de interlocução específica para as problemáticas envolvendo o Esoterismo. E, para ambas, a solução veio do mesmo lugar: a internet. Ainda que seja uma ferramenta a ser utilizada com muita cautela, a internet me possibilitou ter acesso a vários documentos digitalizados por instituições sérias, como a Bibliothèque Nationale de France e a Bayerische Staatsbibliothek, dentre outras. Também através da internet eu pude manter contato com pesquisadores com larga experiência sobre temas envolvendo esse diálogo entre o esoterismo e a Idade Média. Dentre eles eu posso destacar o Professor Peter Forshaw (UvA), o Professor Nicolas WeillParot (UPEC), que colaborou com a Professora Adriana Vidotte (UFG) na minha orientação e o Professor Juan Pablo Bubello (UBA), quem não apenas me ofereceu seu conhecimento mas também a oportunidade de dividir a responsabilidade de coordenar um centro de pesquisa como o Centro de Estudios sobre el Esoterismo Occidental de la UNASUR.

¿Cuáles fueron las principales problemáticas históricas que su trabajo ha resuelto?

A pesquisa começou com uma inquietação acerca das relações entre os "homens de poder" e os "esoteristas" no século XVI europeu. Eu me indagava quais os motivos que fizeram com que imperadores, reis e papas mantivessem tais homens por perto. Como também porque tais homens manifestaram abertamente suas concepções esotéricas sobre temas religiosos, entre outros, sofrendo consequências menores, ou mesmo não sendo importunados por isso. Tudo isso num cenário histórico onde havia grande preocupação com a defesa da ortodoxia católica. Através de obras como a Steganographia e o De Furtivis Literarum Notis eu pude perceber que havia um ponto para onde os interesses de todas essas personagens históricas convergiam: o segredo. Dessa forma, o segredo como relação social de poder acabou se tornando um dos eixos centrais do meu trabalho, da minha pesquisa. Busquei compreender como o segredo conseguiu canalizar concepções esotéricas vigentes à época, recuperadas do hermetismo e da cabala, para o palco da ação política. Sendo um pouco mais incisivo, refleti sobre como a apropriação das concepções esotéricas do segredo foram empregadas na transição política entre o Regimen Animarum medieval e a Razão de Estado, vinculado ao que entendemos por Estado Moderno, com todas as problemáticas que tal termo implica. Além dessa discussão macroscópica, existe também um esforço em ao menos esboçar uma perspectiva microscópica, ou seja, busquei dedicar alguns momentos para pensar estes sujeitos em sua individualidade, tentando 
compreender quais intenções os fizeram percorres estes caminhos.

¿Por favor, podría resumir la esencia de su Tesis en dos líneas?

Essa é uma tarefa difícil, mas vamos lá: em minha tese busquei compreender como a concepção esotérica de segredo influenciou na construção das linguagens de segredo tão importantes na passagem do Regimen medieval para a Razão de Estado moderna.

¿Cuáles fueron las lecciones, a todos los niveles, personal y profesional, que usted ha deducido de su experiencia investigativa?

Realmente, produzir uma tese é uma tarefa árdua, que afeta sua vida em diversos níveis. É na verdade um projeto de vida, um que demanda um alto grau de dedicação e renúncia. Frequentemente foi preciso sacrificar aspectos da minha vida pessoal para que eu pudesse obter os meios para a realização desse projeto. Ficou ainda mais firme para mim a necessidade de um bom planejamento de trabalho para a pesquisa. Uma vez que mesmo com ele as coisas não saem conforme o planejado, sem ele o risco da pesquisa se perder no caos é enorme. Essa dedicação ao planejamento deve ser aliada a uma grande flexibilidade, pois são frequentes as oportunidades nas quais a direção da pesquisa deve ser readequada, seja pelo trabalho com as fontes, pela interlocução com outros pesquisadores ou por circunstâncias da vida. É fundamental também buscar o diálogo, de forma franca, aberta e humilde. Aprendi muito com historiadores com mais experiência do que eu a lidar com um projeto de trabalho desse porte, a buscar as melhores direções para o trabalho, a realizar a leitura a contrapelo da qual Marc Bloch falou. Além disso, tais pesquisadores já haviam trilhado o caminho que eu trilhava, portanto puderam me ajudar a superar esse desafio. Por isso, é fundamental um bom trabalho de orientação e de articulação acadêmica. Junto dessa humildade, como pessoa e como pesquisador, é pedra angular de uma empreitada dessas o porto seguro oferecido pelos entes queridos, donde se retira forças para concluir uma tarefa que por vezes parece impossível de ser concluída. Quanto a isso, só tenho o que agradecer, principalmente a minha esposa.

¿Ahora, cuáles son sus proyectos profesionales?

Meu projeto mais imediato é obter uma posição permanente como docente em uma universidade. Dessa forma, eu entendo que teria uma condição melhor tanto para desenvolver minhas pesquisas quanto para ampliar e consolidar a atuação do CEEOUNASUR em solo brasileiro. Contudo, estamos passando por momento político e econômico conturbado no Brasil, que tem dificultado a realização dessa meta. Sendo assim, 
começo a planejar um projeto de pesquisa, a ser possivelmente realizado através de um estágio de pós-doutorado, para pensar como a questão política aparece na obra de Johannes Trithemius chamada De Septem Secundeis. Essa que é uma das últimas obras do abade alemão, foi dedicada à reflexão sobre a influência que os anjos teriam na vida dos astros e dos homens. Ele deu continuidade à ideia de que o mundo criado seria governado, de forma alternada, por anjos vinculados aos planetas, sendo estas entidades angélicas responsáveis por agir o spiritus planetário sobre o mundo sublunar. Tenho na vida e na obra de Trithemius um dos meus principais objetos de pesquisa, e acredito que essa obra é muito rica para uma análise a partir de um diálogo entre a História do Esoterismo e a História Política. Também estou preparando a versão final da minha tese, tendo em mente buscar por oportunidades de publicá-la.

¿Quisiera destacar algún aspecto que no se ha contemplado y que usted consideraría digno de reseñar?

Eu gostaria de agradecer à REHMLAC a oportunidade de divulgar minha pesquisa através de sua revista. Também quero parabenizar pelo empreendimento de sucesso que a REHMLAC é, pois desenvolver pesquisas acadêmicas de qualidade em temáticas como a maçonaria na América Latina é muito importante para que se possa compreender de maneira mais abrangente a nossa trajetória histórica. Encerro convidando a todos que visitem o blog do CEEO-UNASUR, nesse endereço http://ceeo-unasur.blogspot.com/. Estamos sempre abertos ao diálogo, às contribuições e às parcerias. Muito obrigado e até a próxima!

Esta entrevista se efectúo de forma telemática el 01 de Setembro de 2015.

Autores de la entrevista: Ricardo Martínez Esquivel e Yván Pozuelo Andrés, Director y Editor de REHMLAC+.

DOI: http://dx.doi.org/10.15517/rehmlac.v7i2.22763 